\title{
PEMILIHAN OBJEK UTAMA CITRA KAWASAN CAGAR BUDAYA JALAN RAJAWALI KOTA SURABAYA
}

\author{
Adelita Virenza Nurubiatmoko, Wara Indira Rukmi, Kartika Eka Sari \\ Jurusan Perencanaan Wilayah dan Kota Fakultas Teknik Universitas Brawijaya \\ Jalan Mayjen Haryono 167 Malang 65145 -Telp (0341)567886 \\ Email: avirenza@gmail.com
}

\begin{abstract}
ABSTRAK
Kawasan Jalan Rajawali merupakan salah satu kawasan cagar budaya yang berkembang menjadi pusat kegiatan komersial. Karakterisitik Jalan Rajawali sebagai pusat kegiatan komersial terlihat dari adanya 27 bangunan cagar budaya yang dimanfaatkan sebagai perkantoran dan perdagangan. Namun seiring berjalannya waktu, kondisi fisik bangunan tersebut yang mengalami kerusakan bahkan hilang dan diganti dengan bangunan baru. Hal tersebut merupakan dampak dari perkembangan kegiatan komersial, yang menyebabkan penurunan nilai budaya dan identitas yang membentuk citra kawasan Jalan Rajawali sebagai kawasan bersejarah. Penelitian ini bertujuan untuk mengetahui objek utama dari masing-masing elemen citra kawasan Jalan Rajawali, sehingga dapat menjadi dasar perencanaan yang memperkuat karakter kawasan. Analisis yang digunakan dalam penelitian ini adalah multi criteria analysis (MCA) dengan menggunakan kriteria organisasi visual pembentuk citra kawasan berdasarkan Teori Gestalt. Hasil mental map menunjukkan bahwa terdapat 5 path, 2 edge, 3 district, 3 node, dan 8 landmark di Kawasan Jalan Rajawali. Hasil MCA menunjukkan bahwa Jalan Rajawali objek utama path, Sungai Kalimas objek utama edge, kawasan cagar budaya objek utama district, Taman Sejarah Jayengrono objek utama node, dan Jembatan Merah objek utama landmark.
\end{abstract}

Kata Kunci: Citra Kawasan, Teori Gestalt, Mental Map, Multi-Criteria-Analysis (MCA)

\section{ABSTRACT}

Jalan Rajawali area is one of the cultural heritage areas that developed into a center of commercial activity. The characteristics of Jalan Rajawali as a center of commercial activity can be seen from the existence of 27 cultural heritage buildings that are used as offices and trade. But over time, the physical condition of the building that was damaged even lost and replaced with new buildings. This is the impact of the development of commercial activities, wich causes decreasing cultural values and identity that build the image of Jalan Rajawali as a historic area. This study aims to determine the main objects of each element of the image of Jalan Rajawali, so that it can be the basis of planning that strengthens the character of the areas. The analysis used in this study is a multi criteria analysis (MCA) using the criteria of visual organization that form the city images based on Gestalt Theory. Mental map showed that there are 5 paths, 2 edges, 3 districts, 3 nodes, and 8 landmarks in the Jalan Rajawali Area. The results of MCA showed that Jalan Rajawali is the main object of path, Kalimas River is the main object of edge, cultural heritage area is the main object of district, Jayengrono Historical Park is the main object of node, and Jembatan Merah is the main object of landmark. The results of crosstab analysis showed that there is a middle strong correlation between commercial activities and each element of the image in the Jalan Rajawali Area.

Keywords: Image of the City, Gestalt Theory, Mental Map, Multi-Criteria-Analysis (MCA)

\section{PENDAHULUAN}

Setiap kota memiliki sejarah yang menggambarkan perkembangan kehidupan dan budaya masyarakat (Marjianto dan Ardiwijaya, 2013 dalam Wati \& Sukmajati, 2010). Hal tersebut terbukti dengan adanya objek atau bangunan cagar budaya pada suatu kawasan bersejarah di setiap kota. Adanya objek atau bangunan tersebut berfungsi untuk memperkuat identitas dan kepribadian bangsa.

Citra kawasan berkaitan erat dengan identitas dari beberapa elemen dalam suatu kota yang berkarakter dan khas sebagai jati diri yang dapat membedakan dengan kota lainnya (Purwanto, 2001). Menurut Kevin Lynch (1960) identitas kota adalah adalah citra mental yang terbentuk dari ritme biologis tempat dan ruang tertentu yang mencerminkan waktu (sense of time), yang ditumbuhkan dari dalam secara mengakar oleh aktivitas sosial-ekonomi-budaya mastarakat kota itu sendiri. Terdapat lima elemen dasar yang digunakan orang untuk menstrukturkan gambaran kognisi dari sejumlah tempat yaitu path, node, district, edge, dan landmark (Lynch, 1960).

Untuk mengetahui objek dan menilai organisasi visual kelima elemen pembentuk citra 
kawasan maka dapat digunakan Teori Gestalt. Teori Gestalt dalam citra kawasan berperan sebagai perangsang visual. Teori Gestalt menyangkut visualitas dan persepsi visual, dan citra kawasan terbentuk dari sensasi dalam berpikir (Eren, 2013).

Kawasan Jalan Rajawali merupakan salah satu kawasan kota lama yang menjadi saksi peristiwa 10 November 1945 di Kota Surabaya. Kawasan kota lama adalah kawasan dengan konsep town planning in Dutch indies, ditandai oleh adanya bangunan kuno bergaya kolonial (Essup, 1985). Jalan Rajawali merupakan salah satu bagian dari pola jalan kota lama dengan nama Hereenstraat (Handinoto, 1996).

Pada tahun 1990-an terjadi property boom di Kota Surabaya yang mengubah wajah Kota Surabaya dengan tampilan baru (Kwanda, 2004). Property boom yaitu kondisi dimana terjadi pembangunan fisik secara besar-besaran dalam pembangunan kota. Kondisi tersebut juga berdampak pada fisik kota lama khususnya Kawasan Jalan Rajawali dengan mempercepat penurunan citra kawasan kota lama, bahkan menghilangkan artefak-artefak sejarah di dalamnya.

Berdasarkan RDTR UP V Tanjung Perak Kota Surabaya Tahun 2018-2038, Kawasan Jalan Rajawali merupakan kawasan yang diperuntukkan sebagai kawasan pengembangan perdagangan dan jasa, serta kawasan perkantoran dengan skala pelayanan regional dan kota, sedangkan berdasarkan RTR Kawasan Strategis Sosial Budaya Tahun 2012-2032, kawasan tersebut termasuk ke dalam zona inti yaitu zona yang dipreservasi untuk mempertahankan karakter kawasan kota lama Surabaya.

Seiring berjalannya waktu Jalan Rajawali mengalami modernisasi dan berkembang menjadi pusat kegiatan komersial sehingga berdampak pada citra kawasan bersejarah (Adiwena, 2015). Oleh karena itu, penelitian perlu dilakukan untuk mengetahui objek utama masing-masing elemen citra kawasan Jalan Rajawali yang dapat digunakan sebagai dasar perencanaan dan memperkuat identitas kawasan sebagai kawasan cagar budaya.

\section{METODE PENELITIAN}

Penelitian menggunakan jenis penelitian deskriptif kuantitatif. Penelitian deskriptif kuantitatif merupakan penelitian yang bertujuan untuk memaparkan dan menafsirkan data yang terjadi pada saat ini, hubungan antarvariabel, pertentangan dua kondisi atau lebih, pengaruh terhadap suatu kondisi, dan perbedaan fakta (Subana, 2005).

\section{Variabel Penelitian}

Variabel yang digunakan didasarkan pada penelitian yaitu variabel kegiatan komersial dan variabel citra kawasan (Tabel 1).

\section{Tabel 1. Variabel Penelitian}

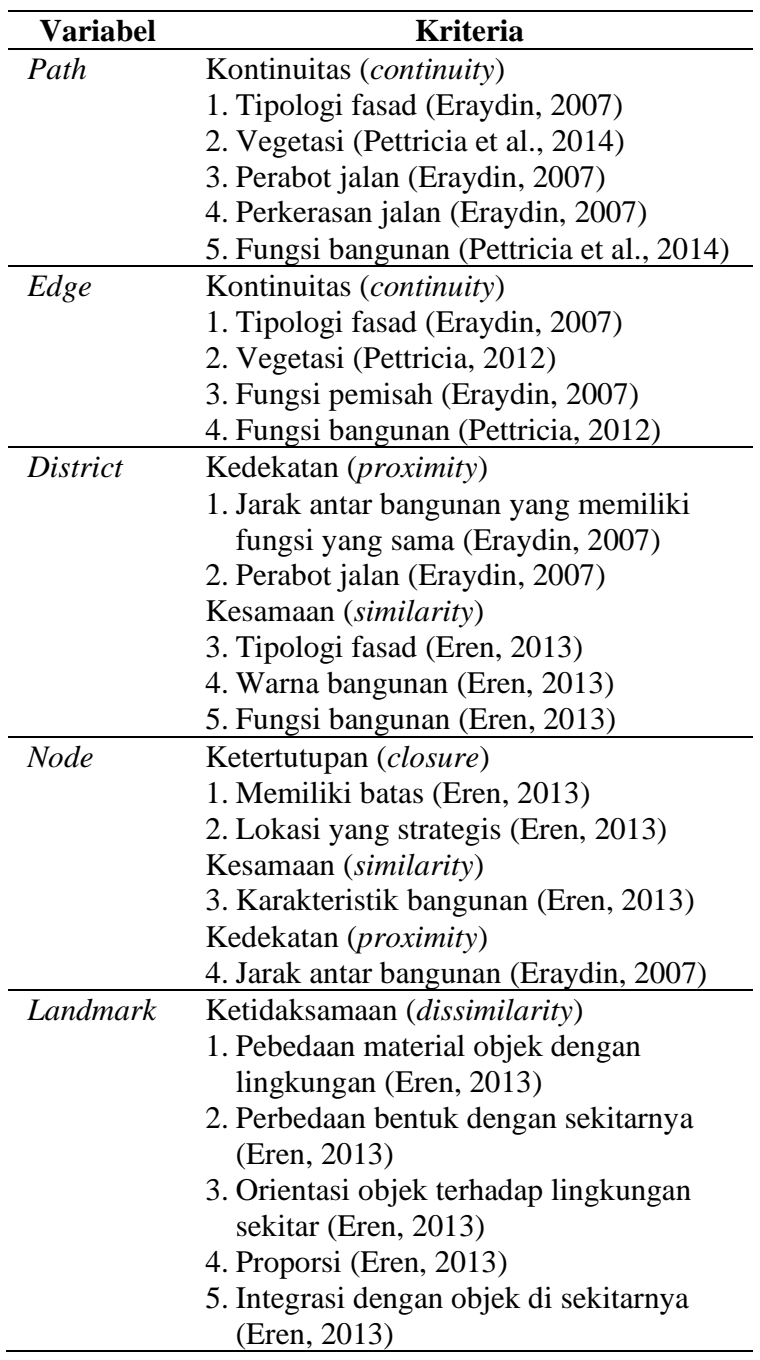

\section{Metode Pengumpulan Data}

Pengumpulan data secara langsung (primer) dengan cara observasi, wawancara, serta kuisioner. Pada penelitian dilakukan observasi citra kawasan dilakukan dengan menggunakan mental map untuk mengetahui objek citra kawasan kepada masyarakat yang tinggal di Kawasan Jalan Rajawali, disertai dengan pengambilan dokumentasi. Data hasil mental map selanjutnya digunakan untuk input objek elemen citra kawasan pada kuesioner MCA. Kemudian dilakukan pembagian kuesioner MCA untuk pemilihan objek utama kepada ahli. 


\section{Populasi dan Sampel}

Sampel pada penelitian antara lain sampel masyarakat dan kelompok ahli.

1. Sampel masyarakat diambil dari masyarakat Kelurahan Krembangan Selatan yang berada dalam delineasi lokasi penelitian, karena dianggap yang paling mengerti lokasi penelitian. Sampel diambil menggunakan teknik non-probability sampling, accidental sampling yaitu pengambilan sampel dari populasi secara acak dan berdasarkan kebetulan/insidental bertemu dengan peneliti. Jumlah sampel masyarakat berjumlah 66 orang, dihitung dengan menggunakan teknik penentuan jumlah linear time function. Sampel masyarakat diseleksi sesuai dengan kriteria, antara lain:

- lama tinggal antara 1-50 tahun: masyarakat dianggap mengerti dan paham gambaran kawasan terkait elemen citra kawasan;

- umur antara 15-59 tahun: masyarakat usia produktif dianggap dapat memahami pengertian masing-masing elemen citra kawasan dan menggambarkan objek elemen citra kawasan.

2. Sampel kelompok ahli diambil dengan menggunakan teknik non-probability sampling, purposive sampling yaitu teknik pengambilan sampel yang menggunakan pertimbangan kriteria tertentu. Kelompok ahli yang dipilih berjumlah 5 orang, dengan kriteria merupakan ahli perancangan perkotaan atau keruangan yang memahami citra kawasan berdasarkan kriteria teori Gestalt.

\section{Metode Analisis}

\section{Multi criteria analysis (MCA)}

Multi criteria analysis (MCA) adalah analisis yang digunakan untuk mengambil keputusan berdasakan persepsi ahli terhadap kriteria-kriteria yang dibandingkan dalam pengambilan keputusan. Metode ini bisa mengakomodasi aspek-aspek di luar kriteria ekonomi dan finansial serta juga bisa mengikut sertakan berbagai pihak yang terkait dengan suatu proyek secara komprehensif dan scientific baik kuantitatif maupun kualitatif (Konidari, 2006).

Pada penelitian, MCA diambil berdasarkan hasil penilaian ahli menggunakan kuesioner yang dibagikan kepada masing-masing ahli. MCA digunakan untuk memperoleh objek utama dari masing-masing elemen citra kawasan di Kawasan Jalan Rajawali. Tahap MCA antara lain:

1. Penentuan kepentingan pada masing-masing kriteria setiap elemen. Berikut merupakan ilustrasi matriks pada kuesioner ahli.

Tabel 2. Matriks Penilaian Kepentingan Kriteria

\begin{tabular}{lccc}
\hline & Kriteria & Kriteria & \\
& $\mathbf{1}$ & $\mathbf{2}$ & dst. \\
\hline Level & & & \\
Kepentingan & $\ldots$ & $\ldots$ & $\ldots$ \\
\hline Bobot & & & \\
Kepentingan & $\ldots$ & $\ldots$ & $\ldots$ \\
\hline
\end{tabular}

2. Skoring objek terhadap kriteria pada masingmasing elemen menggunakan skala likert. Pada penelitian, digunakan interval penilaian $1-5$, dengan 1 nilai terendah. Berikut merupakan ilustrasi matriks pada kuesioner ahli.

Tabel 3. Matriks Penilaian Objek

\begin{tabular}{lccccccccccc}
\hline \multirow{2}{*}{ Kriteria } & \multicolumn{4}{c}{ Alternatif 1 } & \multicolumn{4}{c}{ Alternatif 2 } \\
\cline { 2 - 10 } & $\mathbf{1}$ & $\mathbf{2}$ & $\mathbf{3}$ & $\mathbf{4}$ & $\mathbf{5}$ & $\mathbf{1}$ & $\mathbf{2}$ & $\mathbf{3}$ & $\mathbf{4}$ & $\mathbf{5}$ \\
\hline 1. Kriteria 1 &. &. &. &. &. &. &. &. &. &. \\
&. &. &. &. &. &. &. &. &. & \\
\hline 2. Kriteria 2 &. &. &. &. &. &. &. &. &. &.. \\
&. &. &. &. &. &. &. &. &. & \\
\hline 3. dst &. &. &. &. &. &. &. &. &. &..
\end{tabular}

3. Penghitungan normalized score yang digunakan untuk menyamaratakan hasil penilaian. Pada penelitian nilai akan disamaratakan dengan interval 0-1. Berikut rumus normalized score:

new score $=\frac{n u b-n l b}{o u b-o l b}($ original score $-o l b)+n l b$

Keterangan:

new score : hasil normalized score

nub : new upper bound (batas interval atas baru $=1$ )

nlb : new lower bound (batas interval bawah baru $=0$ )

oub : original upper bound (batas interval atas awal $=5$ )

olb : original lower bound (batas interval bawah awal $=1$ )

original score: data skoring 


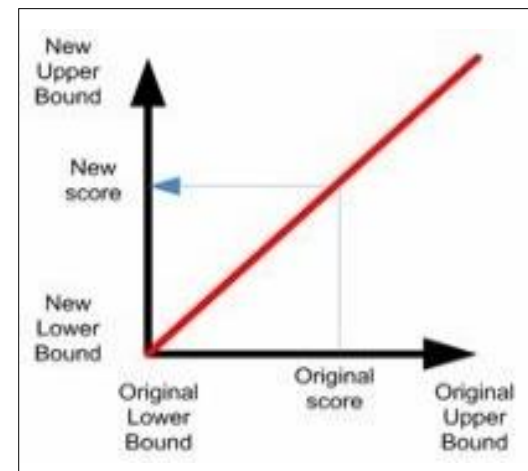

Gambar 1. Sumbu Normalized Score

4. Penghitungan pembobotan yang berfungsi untuk mengetahui skor tertinggi dan memilih objek utama, dengan cara menghitung level kepentingan dan normalized score. Hasil dari masing-masing kriteria pada masing-masing objek dijumlahkan dan didapatkan total pembobotan masing-masing objek. Objek yang memiliki total pembobotan tertinggi yang merupakan objek utama citra kawasan.

\section{HASIL DAN PEMBAHASAN}

\section{A. Karakteristik Kawasan Jalan Rajawali}

Kawasan Jalan Rajawali terletak di Kelurahan Krembangan Selatan Kecamatan Krembangan Kota Surabaya. Berdasarkan hasil survei primer, Kawasan Jalan Rajawali memiliki luas 45,90 Ha. Secara administratif batas-batas lokasi penelitian sebagai berikut:

Sebelah Utara : Jalan Pesapen Selatan, Jalan Nelayan

Sebelah Timur : Jalan Indrapura

Sebelah Selatan : Jalan Krembangan Makam, Jalan Merak, Jalan Cendrawasih

Sebelah Barat : Sungai Kalimas

Guna lahan Kawasan Jalan Rajawali dijelaskan pada Tabel 4.

Tabel 4. Guna Lahan Kawasan Jalan Rajawali

\begin{tabular}{|c|c|c|}
\hline Guna Lahan & $\begin{array}{l}\text { Luas } \\
\text { (Ha) }\end{array}$ & $\begin{array}{c}\text { Prosentase } \\
(\%)\end{array}$ \\
\hline Jalan & 10,23 & $22,29 \%$ \\
\hline Industri dan Pergudangan & 2,74 & $5,97 \%$ \\
\hline Pendidikan & 1,65 & $3,59 \%$ \\
\hline Perdagangan dan Jasa & 17,51 & $38,15 \%$ \\
\hline Perkantoran & 2,46 & $5,36 \%$ \\
\hline Permukiman & 2,63 & $5,73 \%$ \\
\hline Pertahanan dan Keamanan & 6,99 & $15,23 \%$ \\
\hline Peruntukan Lainnya & 0,88 & $1,92 \%$ \\
\hline RTH & 0,81 & $1,76 \%$ \\
\hline Total & 45,90 & $100 \%$ \\
\hline
\end{tabular}

Sumber: Hasil Survei Primer, 2019
Kawasan Jalan Rajawali didominasi dengan guna lahan perdagangan dan jasa dengan luas $17,51 \mathrm{Ha}(38,15 \%)$.

Sejarah perkembangan Kawasan Jalan Rajawali yang sangat berpengaruh hingga menjadi pusat kegiatan komersial yaitu pada tahun 18701945, Indonesia mengalami desentralisasi. Surabaya mengalami perkembangan fisik dan tumbuh menjadi kota modern ditandai dengan Benteng Prins Hendrik yang mulai diruntuhkan pada tanggal 19 April 1871, sehingga Hereenstraat mulai berkembang dan menjadi pusat kegiatan komersial di pusat kota. Peninggalan bangunan kolonial juga masih ada hingga kini dan menjadi bangunan cagar budaya dengan jumlah 27 unit (SK Walikota Surabaya tentang Bangunan Cagar Budaya).

\section{B. Karakteristik Responden}

Responden pada penelitian yaitu kelompok sampel masyarakat dan kelompok sampel ahli. Kedua kelompok responden tersebut digunakan dalam menentukan elemen citra kawasan di Kawasan Jalan Rajawali.

Sampel masyarakat yang dipilih adalah masyarakat yang tinggal di Kawasan Jalan Rajawali. Masyarakat dipilih menjadi responden dalam penelitian karena masyarakat yang tinggal di kawasan tersebut dianggap paham dengan kondisi lokasi penelitian. Berdasarkan hasil perhitungan jumlah sampel, masyarakat yang diambil pada penelitian yaitu 66 orang yang terbagi dalam 6 segmen. Berikut karakteristik responden pada lokasi penelitian.

Tabel 5. Karakteristik Responden Masyarakat

\begin{tabular}{|c|c|c|c|c|c|c|c|c|c|}
\hline \multirow[t]{2}{*}{ No } & \multicolumn{2}{|c|}{ Data } & \multicolumn{6}{|c|}{ Pembagian Segmen } & \multirow[t]{2}{*}{ Jumlah } \\
\hline & & & 1 & 2 & 3 & 4 & 5 & 6 & \\
\hline \multirow[t]{3}{*}{1.} & Jenis & $\mathrm{L}$ & 5 & 6 & 7 & 5 & 9 & 4 & 36 \\
\hline & Kelamin & $\mathrm{P}$ & 4 & 5 & 7 & 2 & 7 & 5 & 30 \\
\hline & & Total & 9 & 11 & 14 & 7 & 16 & 9 & 66 \\
\hline \multirow[t]{9}{*}{2.} & $\begin{array}{l}\text { Umur } \\
\text { (tahun) }\end{array}$ & $\begin{array}{l}20- \\
24\end{array}$ & 1 & 1 & 1 & 1 & 2 & 1 & 7 \\
\hline & & $\begin{array}{l}25- \\
29\end{array}$ & 2 & 2 & 3 & 2 & 3 & 2 & 14 \\
\hline & & $\begin{array}{l}30- \\
34\end{array}$ & 2 & 1 & 1 & 1 & 3 & 1 & 9 \\
\hline & & $\begin{array}{l}35- \\
39\end{array}$ & 3 & 2 & 4 & 1 & 3 & 2 & 15 \\
\hline & & $\begin{array}{c}40- \\
44\end{array}$ & 1 & 2 & 3 & - & 2 & 1 & 9 \\
\hline & & $\begin{array}{l}45- \\
49\end{array}$ & - & 2 & - & 1 & 2 & 1 & 6 \\
\hline & & $\begin{array}{c}50- \\
54\end{array}$ & - & - & 1 & - & - & 1 & 2 \\
\hline & & $\begin{array}{c}55- \\
59 \\
\end{array}$ & - & 1 & 1 & 1 & 1 & - & 4 \\
\hline & & Total & 9 & 11 & 14 & 7 & 16 & 9 & 66 \\
\hline
\end{tabular}




\begin{tabular}{|c|c|c|c|c|c|c|c|c|c|}
\hline \multirow[t]{2}{*}{ No } & \multirow{2}{*}{\multicolumn{2}{|c|}{ Data }} & \multicolumn{6}{|c|}{$\begin{array}{c}\text { Pembagian Segmen } \\
\text { Pengambilan Sampel } \\
\end{array}$} & \multirow[t]{2}{*}{ Jumlah } \\
\hline & & & 1 & 2 & 3 & 4 & 5 & 6 & \\
\hline \multirow[t]{7}{*}{3.} & Lama & $<1$ & - & 1 & 1 & - & - & 2 & 4 \\
\hline & Tinggal & $1-10$ & 6 & 4 & 3 & 2 & 6 & 3 & 24 \\
\hline & (tahun) & $\begin{array}{l}11- \\
20\end{array}$ & 2 & 2 & 4 & 4 & 3 & 1 & 16 \\
\hline & & $\begin{array}{l}21- \\
30\end{array}$ & 1 & 2 & 3 & - & 4 & 1 & 11 \\
\hline & & $\begin{array}{l}31- \\
40\end{array}$ & - & 1 & 2 & 1 & 1 & 1 & 6 \\
\hline & & $\begin{array}{l}41- \\
50\end{array}$ & - & 1 & 1 & - & 2 & 1 & 5 \\
\hline & & Total & 9 & 11 & 14 & 7 & 16 & 9 & 66 \\
\hline
\end{tabular}

Sumber: Hasil Survei Primer, 2019

Tabel 5. menunjukkan bahwa sampel masyarakat didominasi oleh laki-laki dengan rentang umur 35-39 tahun dan lama tinggal 1-10 tahun di Kawasan Jalan Rajawali yang membuktikan masyarakat mengerti dan paham, serta dapat menggambarkan gambaran kawasan terkait elemen citra kawasan.

Pada sampel ahli, dipilih karena dianggap sebagai responden yang dapat memahami dan dapat menerjemahkan hasil presepsi citra kawasan menurut masyarakat awam dengan teori citra kawasan. Sampel ahli yang dipilih merupakan 5 orang dosen dari Institut Teknologi Sepuluh Nopember dengan spesifikasi keahlian:

- Narasumber ahli 1 (Ahli perancangan perkotaan dan urban heritage)

- Narasumber ahli 2 (Ahli perancangan perkotaan)

- Narasumber ahli 3 (Ahli perencanaan keruangan)

- Narasumber ahli 4 (Ahli perancangan perkotaan)

- Narasumber ahli 5 (Ahli perancangan perkotaan dan urban heritage)

\section{Objek Utama Citra Kawasan}

Pemilihan objek dari masing-masing elemen citra kawasan pada penelitian ini menggunakan mental map dari masyarakat dan penentuan objek utama pada masing-masing elemen citra kawasan menggunakan multi criteria analysis (MCA) dengan penilaian kriteria oleh ahli berdasarkan Teori Gestalt.

\section{Path}

Elemen path di Kawasan Jalan Rajawali yang terpilih berupa jalan. Terdapat 20 ruas jalan, namun jalan yang muncul pada mental map responden masyarakat berjumlah 5 ruas yaitu Jalan Rajawali, Jalan Kasuari, Jalan Taman Jayengrono, Jalan Kalimas Barat, dan Jalan Jembatan Merah.

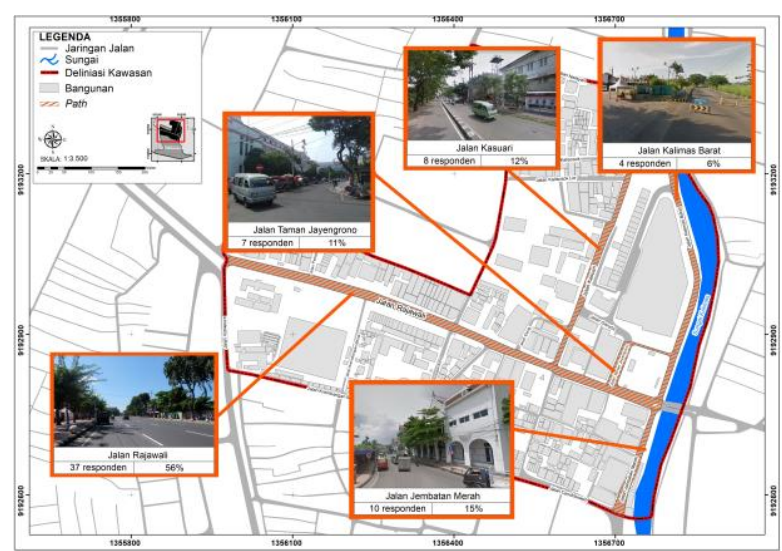

Gambar 2. Objek Elemen Path berdasarkan Persepsi Masyarakat

Kriteria elemen path berdasarkan Teori Gestalt pada penelitian ini, antara lain:

1) Kesamaan tipologi fasad

2) Keberadaan vegetasi

3) Keberadaan perabot jalan

4) Perkerasan jalan

5) Kesamaan fungsi bangunan

Tabel 6. Penilaian MCA Elemen Path

\begin{tabular}{|c|c|c|c|c|c|c|c|}
\hline \multirow{2}{*}{ Objek } & \multicolumn{5}{|c|}{ Kriteria } & \multirow{2}{*}{ Total } & \multirow{2}{*}{ Prosentase } \\
\hline & 1 & 2 & 3 & 4 & 5 & & \\
\hline $\begin{array}{l}\text { Jalan } \\
\text { Rajawali }\end{array}$ & 1,9 & 1,2 & 0,67 & 0,67 & 0,23 & 4,67 & $26,05 \%$ \\
\hline $\begin{array}{l}\text { Jalan } \\
\text { Kasuari } \\
\end{array}$ & 1,4 & $\begin{array}{l}0,9 \\
3 \\
\end{array}$ & 0,27 & 0,53 & 0,22 & 3,35 & $18,70 \%$ \\
\hline $\begin{array}{l}\text { Jalan } \\
\text { Taman } \\
\text { Jayengron } \\
\text { o } \\
\end{array}$ & 1,6 & 0,4 & 0,6 & 0,6 & 0,12 & 3,32 & $18,51 \%$ \\
\hline $\begin{array}{l}\text { Jalan } \\
\text { Kalimas } \\
\text { Barat }\end{array}$ & 0,8 & $\begin{array}{l}1,1 \\
3\end{array}$ & 0,33 & 0,57 & 0,13 & 2,97 & $16,56 \%$ \\
\hline $\begin{array}{l}\text { Jalan } \\
\text { Jembatan } \\
\text { Merah }\end{array}$ & 1,5 & $\begin{array}{l}0,9 \\
3 \\
\end{array}$ & 0,57 & 0,43 & 0,18 & 3,62 & $20,19 \%$ \\
\hline
\end{tabular}




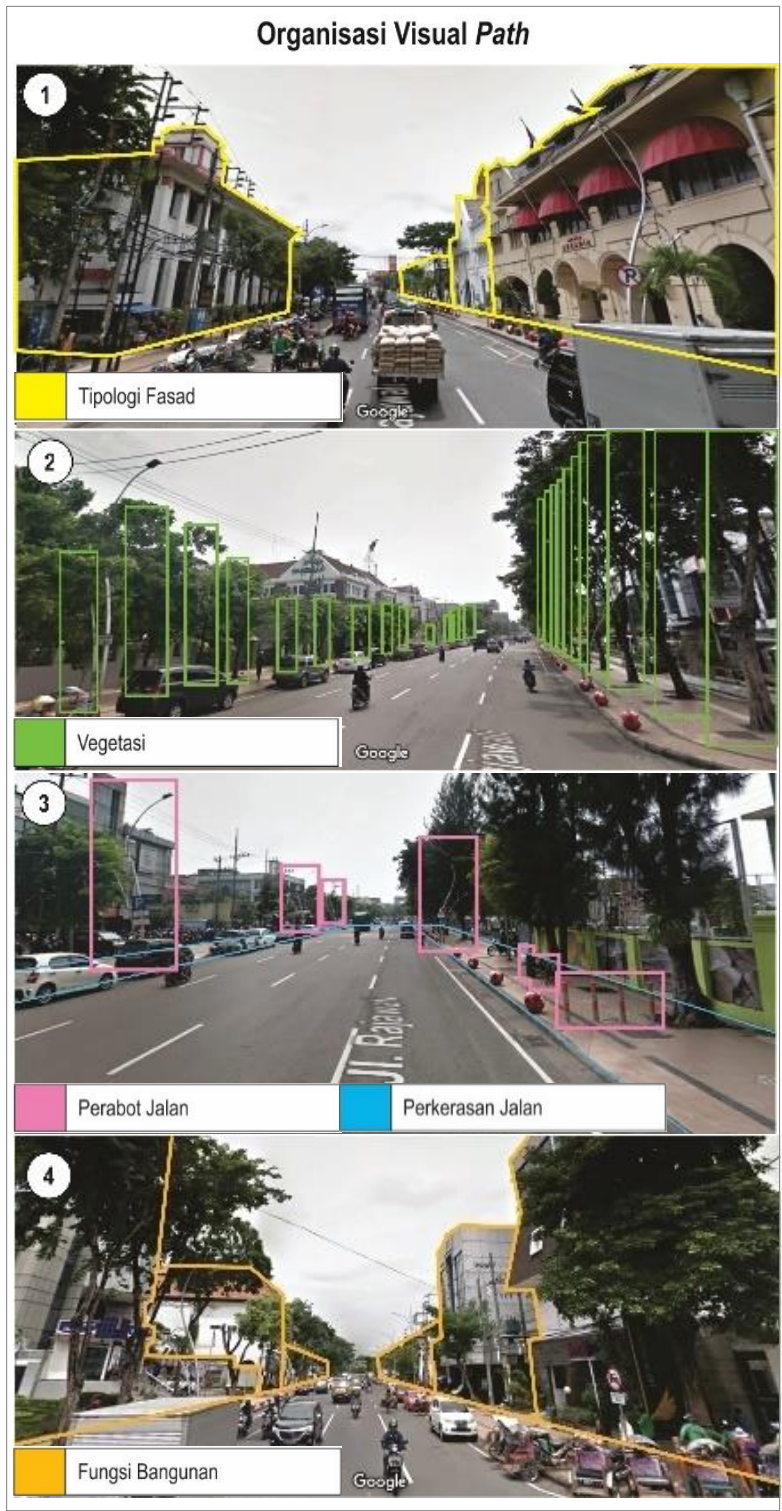

Gambar 3. Organisasi Visual Elemen Path

Kesamaan tipologi facade

Objek yang memiliki nilai tertinggi untuk kriteria tipologi facade pada elemen path di Kawasan Jalan Rajawali yaitu Jalan Rajawali. Facade di sepanjang Jalan Rajawali memiliki kesamaan tipologi yang khas kolonial berupa bentuk bangunan yang simetris, skala bangunan yang tinggi, memiliki bukaan dengan jumlah banyak dan ukuran yang besar, atap dengan gavel cenderung berbentuk segitiga. Selain itu juga memiliki warna yang selaras dan cenderung monokrom yang memperkuat pola continuity.

Keberadaan vegetasi

Objek yang memiliki nilai tertinggi untuk kriteria vegetasi pada elemen path di Kawasan Jalan Rajawali yaitu Jalan Rajawali. Vegetasi berada di sepanjang jalan dengan jarak tanam yang teratur yaitu setiap 3 meter yang memperkuat pola continuity.

Keberadaan perabot jalan

Objek yang memiliki nilai tertinggi untuk kriteria perabot jalan pada elemen path di Kawasan Jalan Rajawali yaitu Jalan Rajawali. Keberadaan pelengkap jalan tersebut berupa lampu penerangan jalan, tempat duduk, tempat sampah, hiasan pedestrian way berbentuk bola, dan pembatas jalan bollard yang teratur semakin memperkuat kesan continuity.

\section{Perkerasan jalan}

Objek yang memiliki nilai tertinggi untuk kriteria perkerasan jalan pada elemen path di Kawasan Jalan Rajawali yaitu Jalan Rajawali. Jalan Rajawali yang dilalui kendaraan satu arah dilengkapi dengan pedestrian way dengan lebar 3 meter yang memperkuat kesan continuity.

\section{Kesamaan fungsi bangunan}

Objek yang memiliki nilai tertinggi untuk kriteria kesamaan fungsi bangunan pada elemen path di Kawasan Jalan Rajawali yaitu Jalan Rajawali. Fungsi bangunan di sepanjang jalan Rajawali mayoritas adalah bangunan komersial baik perdagangan, jasa, maupun industri. Kesamaan fungsi bangunan tersebut dapat dilihat melalui adanya signage bangunan, etalase, parkir on street, dan pelengkap lainnya yang menandakan adanya kegiatan komersial pada bangunan tersebut.

Nilai akhir pembobotan kriteria elemen path, objek yang memiliki nilai tertinggi adalah Jalan Rajawali dengan prosentase 26,05\% dan menjadi objek utama elemen path di Kawasan Jalan Rajawali.

\section{Edge}

Elemen edge di Kawasan Jalan Rajawali berdasarkan mental map berupa jalan dan sungai, yaitu Sungai Kalimas dan Jalan Indrapura. Kriteria elemen edge berdasarkan Teori Gestalt pada penelitian ini, antara lain:

1) Kesamaan tipologi fasad

2) Keberadaan vegetasi

3) Kejelasan fungsi pemisah

4) Kesamaan fungsi bangunan 


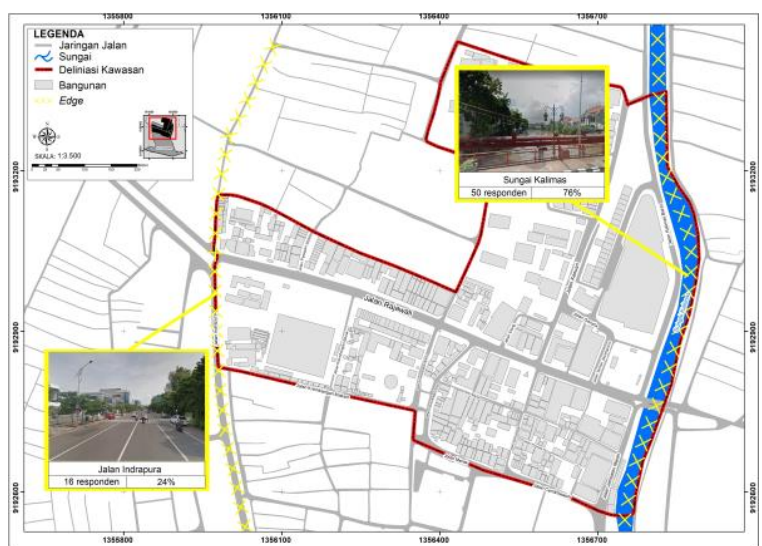

Gambar 4. Objek Elemen Edge berdasarkan Persepsi Masyarakat

Tabel 7. Penilaian MCA Elemen Edge

\begin{tabular}{|c|c|c|c|c|c|c|}
\hline \multirow{2}{*}{ Objek } & \multicolumn{4}{|c|}{ Kriteria } & \multirow{2}{*}{$\begin{array}{c}\text { Tota } \\
1\end{array}$} & \multirow{2}{*}{$\begin{array}{c}\text { Prosenta } \\
\text { se }\end{array}$} \\
\hline & 1 & 2 & 3 & 4 & & \\
\hline $\begin{array}{l}\text { Sungai } \\
\text { Kalimas }\end{array}$ & $\begin{array}{l}0,5 \\
9\end{array}$ & $\begin{array}{l}0,9 \\
4\end{array}$ & 2,5 & $\begin{array}{l}0,2 \\
5\end{array}$ & 4,28 & $55,24 \%$ \\
\hline $\begin{array}{l}\text { Jalan } \\
\text { Indrapur } \\
\text { a }\end{array}$ & $\begin{array}{l}0,1 \\
9\end{array}$ & $\begin{array}{l}1,0 \\
6\end{array}$ & $\begin{array}{l}1,7 \\
5\end{array}$ & $\begin{array}{l}0,4 \\
7\end{array}$ & 3,47 & $44,76 \%$ \\
\hline
\end{tabular}

Sumber: Hasil Analisis, 2019

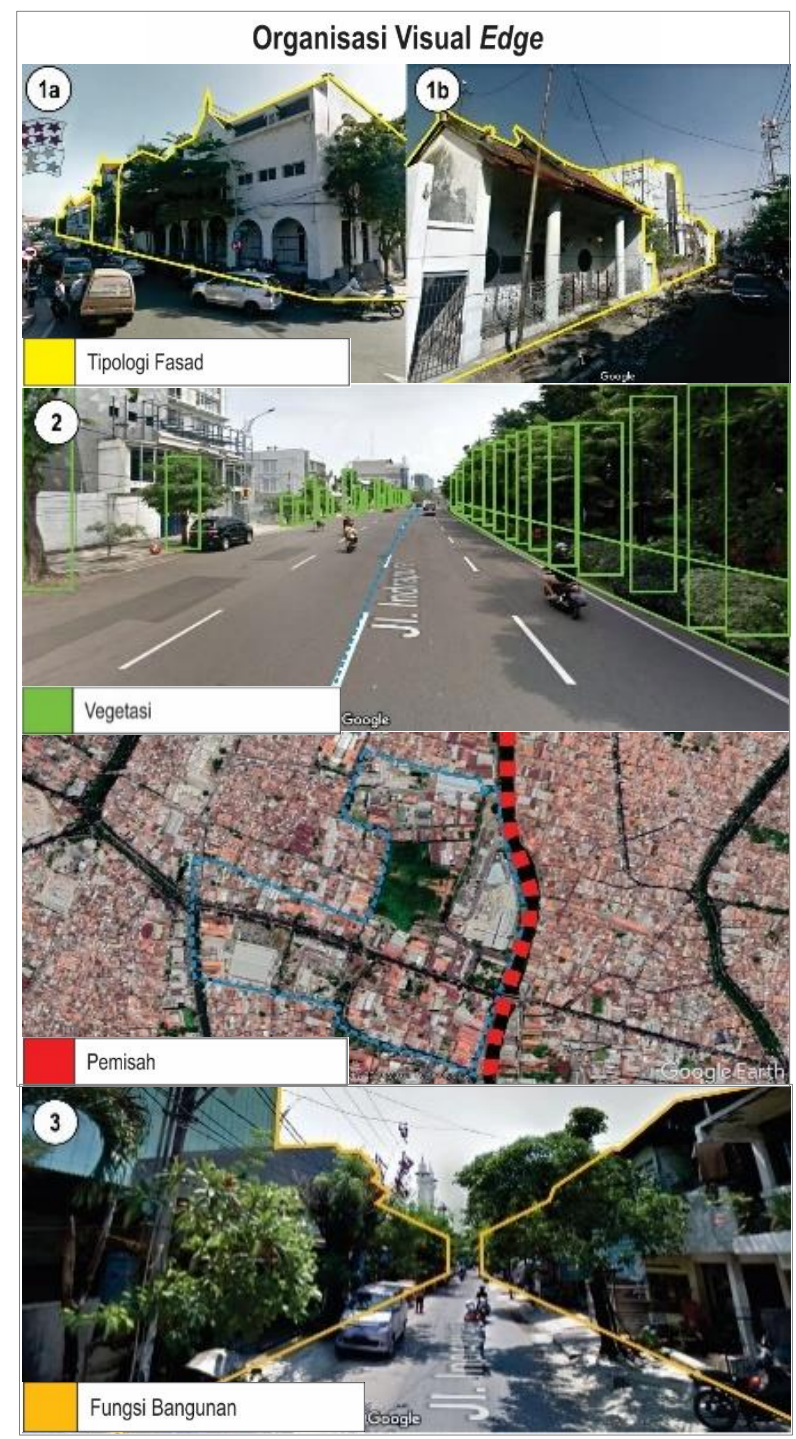

Gambar 5. Organisasi Visual Elemen Edge
Kesamaan tipologi facade

Objek yang memiliki nilai tertinggi untuk kriteria tipologi facade pada elemen edge di Kawasan Jalan Rajawali yaitu Sungai Kalimas. Facade di kedua sisi sungai memiliki tipologi yang berbeda. Pada sisi timur sungai merupakan Kawasan Pecinan yang memiliki facade khas Cina (1b). Sedangkan di bagian barat sungai, tipologi yang facade yang khas adalah kolonial (1a). Perbedaan bangunan di kedua sisi tersebut memperkuat pola continuity.

\section{Keberadaan vegetasi}

Objek yang memiliki nilai tertinggi untuk kriteria vegetasi pada elemen edge di Kawasan Jalan Rajawali yaitu Jalan Indrapura. Vegetasi yang berada di sepanjang jalan memiliki perbedaan di kedua sisinya. Pada sisi timur, vegetasi tidak ditanam secara teratur. Sedangkan di sisi barat, vegetasi yang ditanam adalah vegetasi dengan jenis pohon sama dan ditata teratur pada jarak tanam 1 meter yang memperkuat pola continuity.

Kontinuitas pemisah

Objek yang memiliki nilai tertinggi untuk kriteria kejelasan fungsi pemisah pada elemen edge di Kawasan Jalan Rajawali yaitu Sungai Kalimas. Sungai Kalimas membagi antara Kawasan Kota Lama yang berada di timur sungai dan Kawasan Pecinan di barat sungai. Sungai sebagai pemisah menggambarkan pola continuity.

\section{Kesamaan fungsi bangunan}

Objek yang memiliki nilai tertinggi untuk kriteria fungsi bangunan pada elemen edge di Kawasan Jalan Rajawali yaitu Jalan Indrapura. Fungsi bangunan di sepanjang Jalan Indrapura di kedua sisi memiliki perbedaan. Pada sisi timur adalah permukiman sedangkan di sisi barat merupakan bangunan komersial. Kesamaan fungsi bangunan pada satu sisi tersebut memperkuat pola continuity.

Hasil pembobotan menunjukkan hasil yang paling tinggi diperoleh Sungai Kalimas dengan prosentase $55,24 \%$ dan menjadi objek utama elemen edge di Kawasan Jalan Rajawali.

\section{District}

Berdasarkan mental map, terdapat tiga kawasan yang mengidentifikasikan elemen district Kawasan Jalan Rajawali. 


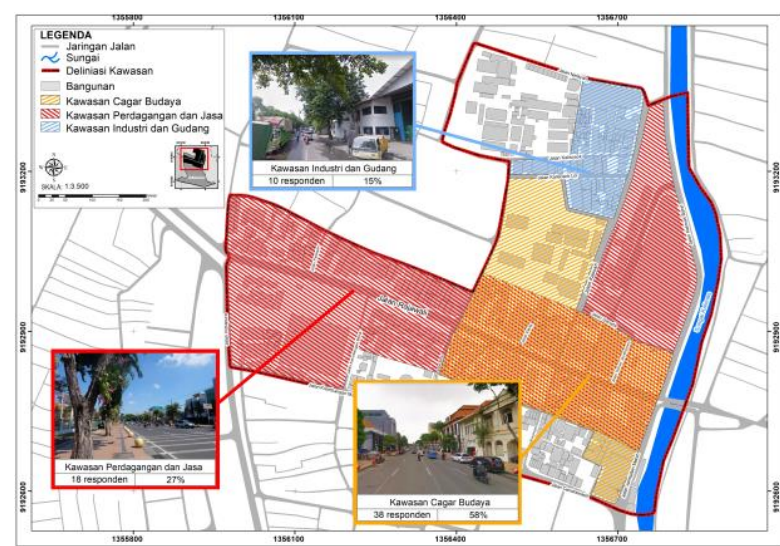

Gambar 6. Objek Elemen District berdasarkan Persepsi Masyarakat

Kriteria elemen district pada penelitian ini, antara lain:

1) Kedekatan bangunan dengan fungsi sama

2) Kedekatan dengan perabot jalan

3) Kesamaan tipologi fasad

4) Kesamaan warna bangunan

5) Kesamaan fungsi bangunan

Tabel 8. Penilaian MCA Elemen District

\begin{tabular}{|c|c|c|c|c|c|c|c|}
\hline \multirow{2}{*}{ Objek } & \multicolumn{5}{|c|}{ Kriteria } & \multirow{2}{*}{ Total } & \multirow{2}{*}{$\begin{array}{l}\text { Prose } \\
\text { ntase }\end{array}$} \\
\hline & 1 & 2 & 3 & 4 & 5 & & \\
\hline $\begin{array}{l}\text { Kawasan } \\
\text { Cagar } \\
\text { Budaya }\end{array}$ & 1,13 & $\begin{array}{l}0,3 \\
1\end{array}$ & $\begin{array}{l}1,1 \\
9\end{array}$ & $\begin{array}{l}0,7 \\
5\end{array}$ & $\begin{array}{l}1,1 \\
3\end{array}$ & 4,5 & $\begin{array}{c}42,17 \\
\%\end{array}$ \\
\hline $\begin{array}{l}\text { Kawasan } \\
\text { Perdaganga } \\
\text { n dan Jasa }\end{array}$ & 1 & $\begin{array}{l}0,2 \\
3\end{array}$ & $\begin{array}{l}0,6 \\
3\end{array}$ & $\begin{array}{l}0,4 \\
7\end{array}$ & $\begin{array}{l}0,8 \\
8\end{array}$ & 3,2 & $\begin{array}{c}\text { 30,01 } \\
\%\end{array}$ \\
\hline $\begin{array}{l}\text { Kawasan } \\
\text { Industri dan } \\
\text { Perdaganga } \\
\mathrm{n}\end{array}$ & 0,75 & $\begin{array}{l}0,0 \\
9\end{array}$ & $\begin{array}{l}0,7 \\
5\end{array}$ & $\begin{array}{l}0,7 \\
5\end{array}$ & $\begin{array}{l}0,6 \\
3\end{array}$ & 2,97 & $\begin{array}{c}27,82 \\
\%\end{array}$ \\
\hline
\end{tabular}

Sumber: Hasil Analisis, 2019

Kedekatan bangunan dengan fungsi sama Kawasan yang memiliki nilai tertinggi untuk kriteria jarak antar bangunan yang memiliki fungsi yang sama pada elemen district di Kawasan Jalan Rajawali yaitu kawasan cagar budaya. Bangunan pada kawasan cagar budaya yang berada di sekitar Jalan Rajawali, Jalan Kasuari, dan Jalan Jembatan Merah mayoritas memiliki fungsi sebagai perkantoran (jasa). Jarak antar bangunan yang berdekatan dan memiliki fungsi yang sama membentuk kelompok kawasan sehingga memperkuat pola proximity.

Kedekatan dengan perabot jalan

Kawasan yang memiliki nilai tertinggi untuk kriteria perabot jalan pada elemen district di Kawasan Jalan Rajawali yaitu kawasan cagar budaya. Kedekatan dengan perabot jalan didominasi oleh kawasan cagar budaya yang berada di Jalan Garuda (1a) dan Jalan Rajawali (1b). Perabot jalan seperti lampu penerangan jalan, tempat duduk, tempat sampah, dan hiasan pedestrian way yang memiliki desain yang sesuai dengan konsep kawasan cagar budaya dan terletak di setiap ruas jalan kawasan cagar budaya membuat kesan proximity semakin kuat di kawasan tersebut.

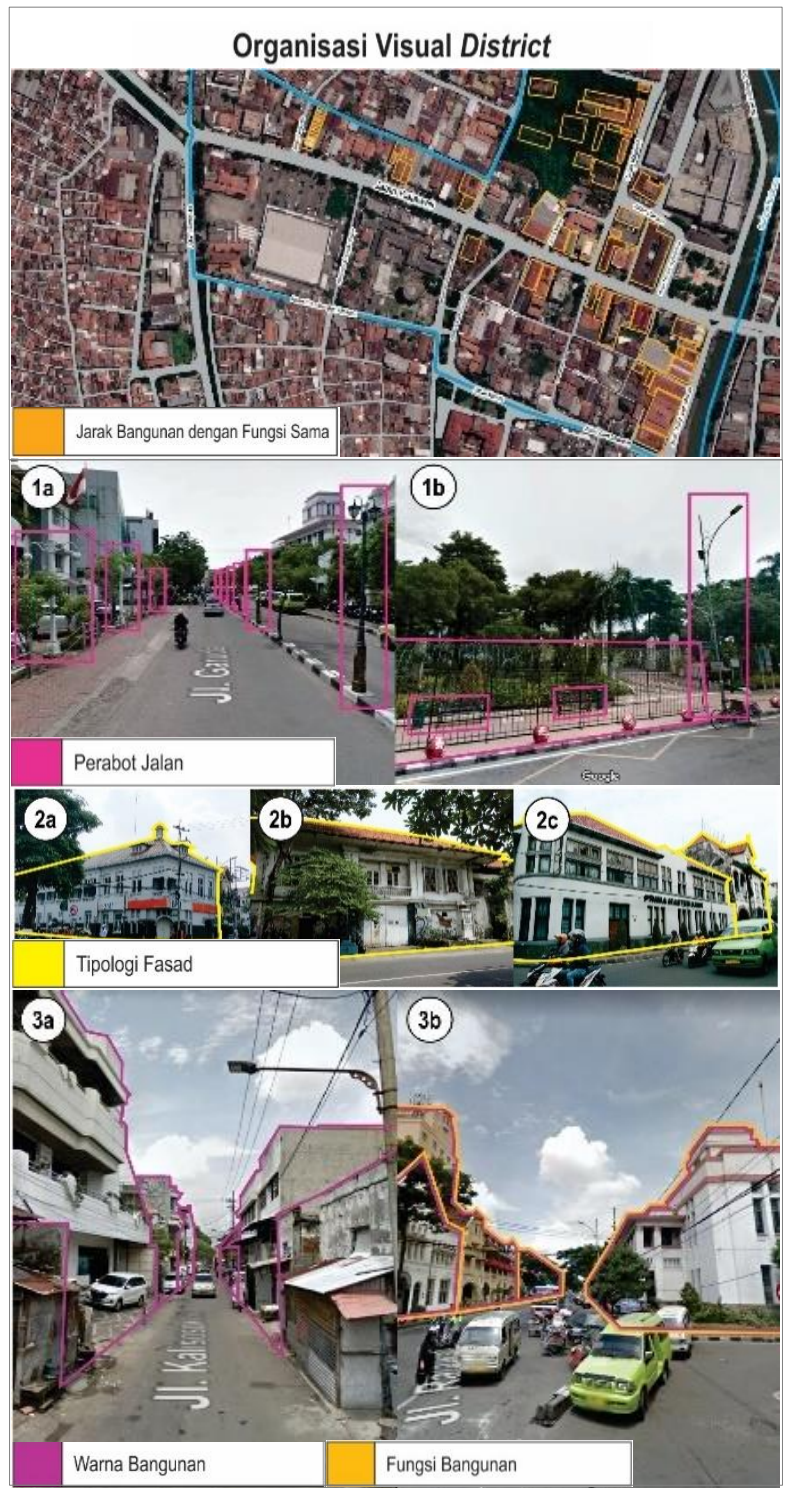

Gambar 7. Organisasi Visual Elemen District

Kesamaan tipologi facade

Kawasan yang memiliki nilai tertinggi untuk kriteria tipologi facade pada elemen district di Kawasan Jalan Rajawali yaitu kawasan cagar budaya. Kawasan cagar budaya memiliki kesamaan tipologi facade khas kolonial yang berada di sepanjang Jalan Rajawali (2a), Jalan Kasuari (2b), dan Jalan Jembatan Merah (2c). Kondisi tersebut membuat kesan similarity pada kawasan semakin kuat. 
Kesamaan warna bangunan

Kawasan yang memiliki nilai tertinggi untuk kriteria warna bangunan pada elemen district di Kawasan Jalan Rajawali yaitu kawasan cagar budaya (3b) serta industri dan gudang (3a). Pada kawasan tersebut memiliki kesamaan warna bangunan yang cenderung pada tone warna selaras yaitu warna klasik (putih, abu-abu, krem, corak hitam) yang memperkuat pola similarity pada kawasan.

Kesamaan fungsi bangunan

Kawasan yang memiliki nilai tertinggi untuk kriteria fungsi bangunan pada elemen district di Kawasan Jalan Rajawali yaitu kawasan cagar budaya. Mayoritas bangunan pada kawasan cagar budaya berfungsi sebagai jasa (3b). Kesamaan tersebut memperkuat pola similarity pada kawasan.

Hasil pembobotan menunjukkan kawasan cagar budaya mendapatkan hasil yang paling tinggi dengan prosentase $42,17 \%$ dan menjadi objek utama elemen district di Kawasan Jalan Rajawali.

\section{4. $\quad$ Node}

Node di Kawasan Jalan Rajawali merupakan titik pusat aktivitas. Node yang terpilih berdasarkan mental map yaitu Taman Sejarah Jayengrono, Jembatan Merah Plaza, dan jalur angkutan umum di Jalan Taman Jayengrono.

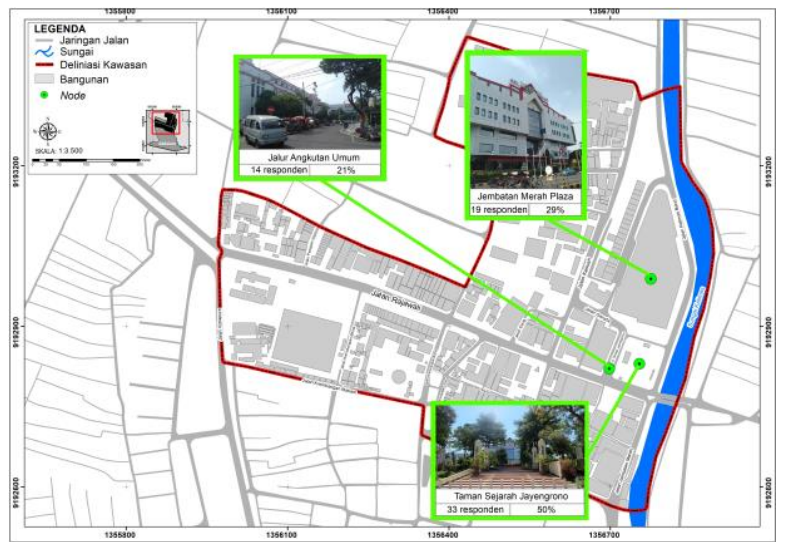

Gambar 8. Objek Elemen Node berdasarkan Persepsi Masyarakat

Kriteria elemen node pada penelitian ini, antara lain:

1) Memiliki batas

2) Lokasi yang strategis

3) Kesamaan karakteristik bangunan

4) Kedekatan jarak antar bangunan
Tabel 9. Penilaian MCA Elemen Node

\begin{tabular}{|c|c|c|c|c|c|c|}
\hline \multirow{2}{*}{ Objek } & \multicolumn{4}{|c|}{ Kriteria } & \multirow{2}{*}{ Total } & \multirow{2}{*}{ Prosentase } \\
\hline & 1 & 2 & 3 & 4 & & \\
\hline $\begin{array}{l}\text { Jalur } \\
\text { Angkutan } \\
\text { Umum }\end{array}$ & 1 & 1,9 & 0,95 & 0,8 & 4,65 & $34,19 \%$ \\
\hline $\begin{array}{l}\text { Jembatan } \\
\text { Merah } \\
\text { Plaza } \\
\end{array}$ & 0,85 & 1,7 & 0,9 & 0,8 & 4,25 & $31,25 \%$ \\
\hline $\begin{array}{l}\text { Taman } \\
\text { Sejarah } \\
\text { Jayengrono }\end{array}$ & 1 & 1,8 & 0,95 & 0,95 & 4,7 & $34,56 \%$ \\
\hline
\end{tabular}

Sumber: Hasil Analisis, 2019

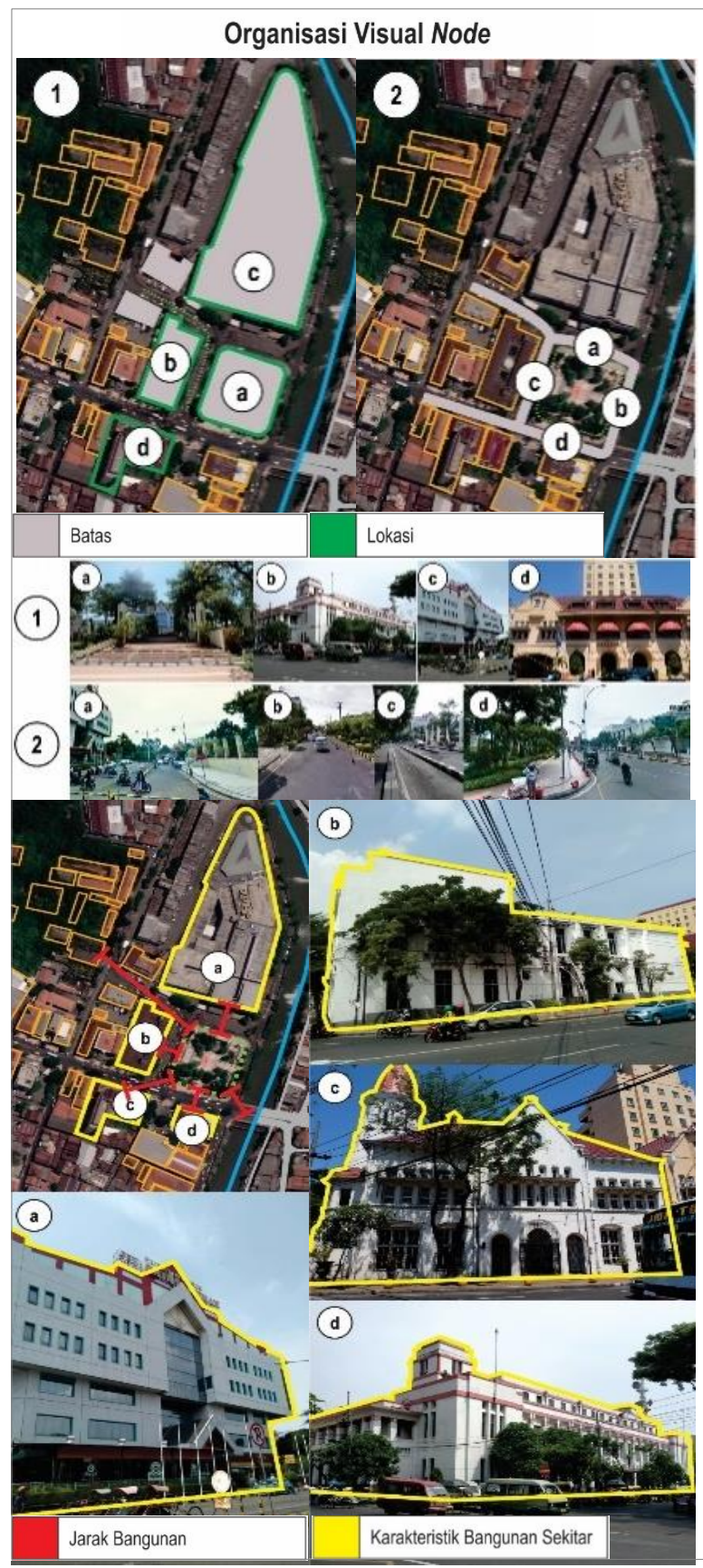

Gambar 9. Organisasi Visual Elemen Node

Memiliki batas

Objek yang memiliki nilai tertinggi untuk kriteria batas pada elemen node di Kawasan Jalan Rajawali yaitu jalur angkutan umum di 
Jalan Taman Jayengrono (1) dan Taman Sejarah Jayengrono (2). Batas pada objek jalur angkutan umum di Jalan Taman Jayengrono berupa Taman Sejarah Jayengrono (1a), Gedung Internatio (1b), Jembatan Merah Plaza (1c), dan Hotel Arcadia (1d). Sedangkan batas pada Taman Sejarah Jayengrono berupa Jalan Taman Jayengrono di sebelah utara (2a), timur (1b), dan barat (2c), serta Jalan Rajawali di sebelah selatan (2d). Kejelasan batas yang dimiliki objek memperkuat pola closure.

\section{Lokasi yang strategis}

Objek yang memiliki nilai tertinggi untuk kriteria lokasi yang strategis pada elemen node di Kawasan Jalan Rajawali yaitu jalur angkutan umum di Jalan Taman Jayengrono. Jalur angkutan umum di Jalan Taman Jayengrono memiliki lokasi yang strategis dan termasuk dalam pusat sirkulasi. Objek tersebut berada di jalan yang terhubung dengan jalan arteri sekunder menuju Madura. Selain itu, objek tersebut juga berada tepat di selatan pusat perbelanjaan Jembatan Merah Plaza, Hotel Arcadia dan kawasan cagar budaya yang dikunjungi wisatawan. Lokasi yang strategis ini semakin memperkuat kesan closure.

Kesamaan karakteristik bangunan

Objek yang memiliki nilai tertinggi untuk kriteria kesamaan bangunan sekitar pada elemen node di Kawasan Jalan Rajawali yaitu jalur angkutan umum di Jalan Taman Jayengrono dan Taman Sejarah Jayengrono. Bangunan yang mengelilingi dua objek tersebut memiliki kesamaan karakteristik bangunan mulai dari tipologi facade dan bentuk bangunan khas kolonial, serta warna bangunan klasik. Kesamaan karakteristik bangunan di sekeliling dua objek tersebut membentuk kelompok yang memperkuat kesan similarity pada kawasan.

Kedekatan jarak antar bangunan

Objek yang memiliki nilai tertinggi untuk kriteria kedekatan jarak antar bangunan pada elemen node di Kawasan Jalan Rajawali yaitu Taman Sejarah Jayengrono. Bangunan yang mengelilingi objek memiliki karakteristik bangunan yang sama dan memiliki jarak yang berdekatan. Kedekatan jarak antar bangunan tersebut membentuk kelompok di sekeliling Taman Sejarah Jayengrono yang menjadi pusat aktivitas sehingga memperkuat pola proximity pada kawasan.
Hasil pembobotan menunjukkan bahwa Taman Sejarah Jayengrono mendapatkan hasil yang paling tinggi dengan prosentase $34,56 \%$ dan menjadi objek utama elemen node di Kawasan Jalan Rajawali.

\section{Landmark}

Objek landmark pada Kawasan Jalan Rajawali yang terpilih berdasarkan mental map yaitu Monumen Komodor Yos Sudarso, Gedung Rajawali, Hotel Arcadia (Hotel Ibis), Gedung Cerutu, Jembatan Merah Plaza, Jembatan Merah, Taman Sejarah Jayengrono, dan Gedung Internatio.

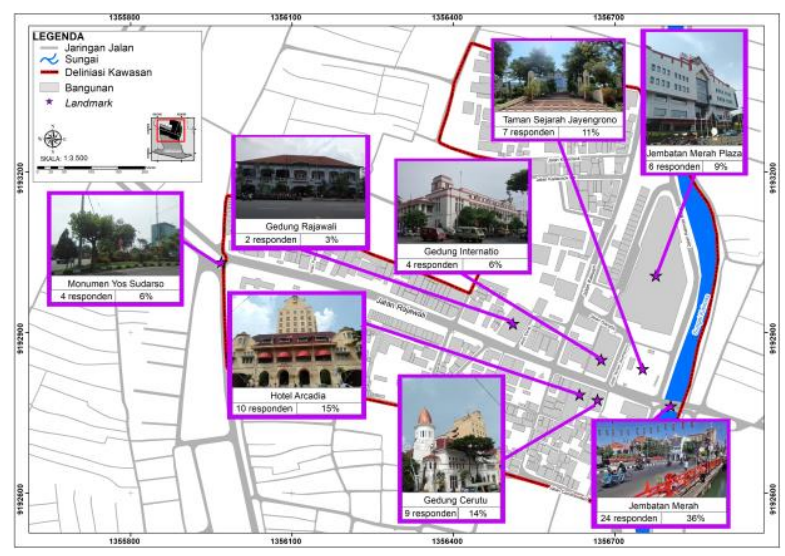

\section{Gambar 10. Objek Elemen Landmark berdasarkan Persepsi Masyarakat}

Kriteria elemen landmark pada penelitian ini, antara lain:

1) Pebedaan material objek dengan lingkungan

2) Perbedaan bentuk dengan sekitarnya

3) Orientasi objek terhadap lingkungan sekitar

4) Proporsi

5) Integrasi dengan objek di sekitarnya

Tabel 9. Penilaian MCA Elemen Landmark

\begin{tabular}{|c|c|c|c|c|c|c|c|}
\hline \multirow[t]{2}{*}{ Objek } & \multicolumn{5}{|c|}{ Kriteria } & \multirow[t]{2}{*}{$\begin{array}{c}\text { Tota } \\
1 \\
\end{array}$} & \multirow[t]{2}{*}{$\begin{array}{c}\begin{array}{c}\text { Pros- } \\
\text { entase }\end{array} \\
\end{array}$} \\
\hline & 1 & 2 & 3 & 4 & 5 & & \\
\hline $\begin{array}{l}\text { Monumen } \\
\text { Yos } \\
\text { Sudarso }\end{array}$ & 0,03 & 1,2 & 0,9 & 0,8 & $\begin{array}{l}0,8 \\
5\end{array}$ & 3,78 & $\begin{array}{c}12,43 \\
\%\end{array}$ \\
\hline $\begin{array}{l}\text { Gedung } \\
\text { Rajawali }\end{array}$ & 0,03 & $\begin{array}{l}0,9 \\
3 \\
\end{array}$ & $\begin{array}{l}0,6 \\
5 \\
\end{array}$ & $\begin{array}{l}0,8 \\
7 \\
\end{array}$ & $\begin{array}{l}0,6 \\
5 \\
\end{array}$ & 3,13 & $\begin{array}{c}10,30 \\
\%\end{array}$ \\
\hline $\begin{array}{l}\text { Gedung } \\
\text { Internatio }\end{array}$ & 0,03 & 0,8 & 0,7 & $\begin{array}{l}0,7 \\
3 \\
\end{array}$ & $\begin{array}{l}0,7 \\
5 \\
\end{array}$ & 3,02 & $\begin{array}{c}9,91 \\
\% \\
\end{array}$ \\
\hline $\begin{array}{l}\text { Taman } \\
\text { Sejarah } \\
\text { Jayengrono }\end{array}$ & 0,3 & $\begin{array}{l}1,1 \\
3\end{array}$ & 0,9 & $\begin{array}{l}1,1 \\
3\end{array}$ & $\begin{array}{l}0,9 \\
5\end{array}$ & 4,42 & $\begin{array}{c}14,51 \\
\%\end{array}$ \\
\hline $\begin{array}{l}\text { Jembatan } \\
\text { Merah } \\
\text { Plaza }\end{array}$ & 0,02 & $\begin{array}{l}1,0 \\
7\end{array}$ & $\begin{array}{l}0,8 \\
5\end{array}$ & $\begin{array}{l}1,0 \\
7\end{array}$ & 0,9 & 3,9 & $\begin{array}{c}12,81 \\
\%\end{array}$ \\
\hline $\begin{array}{l}\text { Jembatan } \\
\text { Merah }\end{array}$ & 0,33 & 1,2 & 1 & $\begin{array}{l}0,9 \\
3 \\
\end{array}$ & 1 & 4,47 & $\begin{array}{c}14,68 \\
\% \\
\end{array}$ \\
\hline
\end{tabular}




\begin{tabular}{lcllllcc}
\hline \multirow{2}{*}{ Objek } & \multicolumn{4}{c}{ Kriteria } & & $\begin{array}{c}\text { Tota } \\
\text { 1 }\end{array}$ & $\begin{array}{c}\text { Pros- } \\
\text { entase }\end{array}$ \\
\cline { 2 - 8 } & $\mathbf{1}$ & $\mathbf{2}$ & $\mathbf{3}$ & $\mathbf{4}$ & $\mathbf{5}$ & & \\
\hline Gedung & 0,05 & $\begin{array}{l}1,2 \\
7\end{array}$ & 0,9 & 1,0 & 0,7 & $\mathbf{4 , 0 3}$ & $\begin{array}{c}\mathbf{1 3 , 2 5} \\
\text { \% }\end{array}$ \\
Cerutu & & 7 & & 5 & & & \\
\hline Hotel & 0,02 & 1,0 & 0,8 & 1 & 0,7 & $\mathbf{3 , 6 8}$ & $\begin{array}{c}\mathbf{1 2 , 1 0} \\
\mathbf{\%}\end{array}$ \\
Arcadia & & 7 & 5 & & 5 & & \\
\hline
\end{tabular}

Sumber: Hasil Analisis, 2019

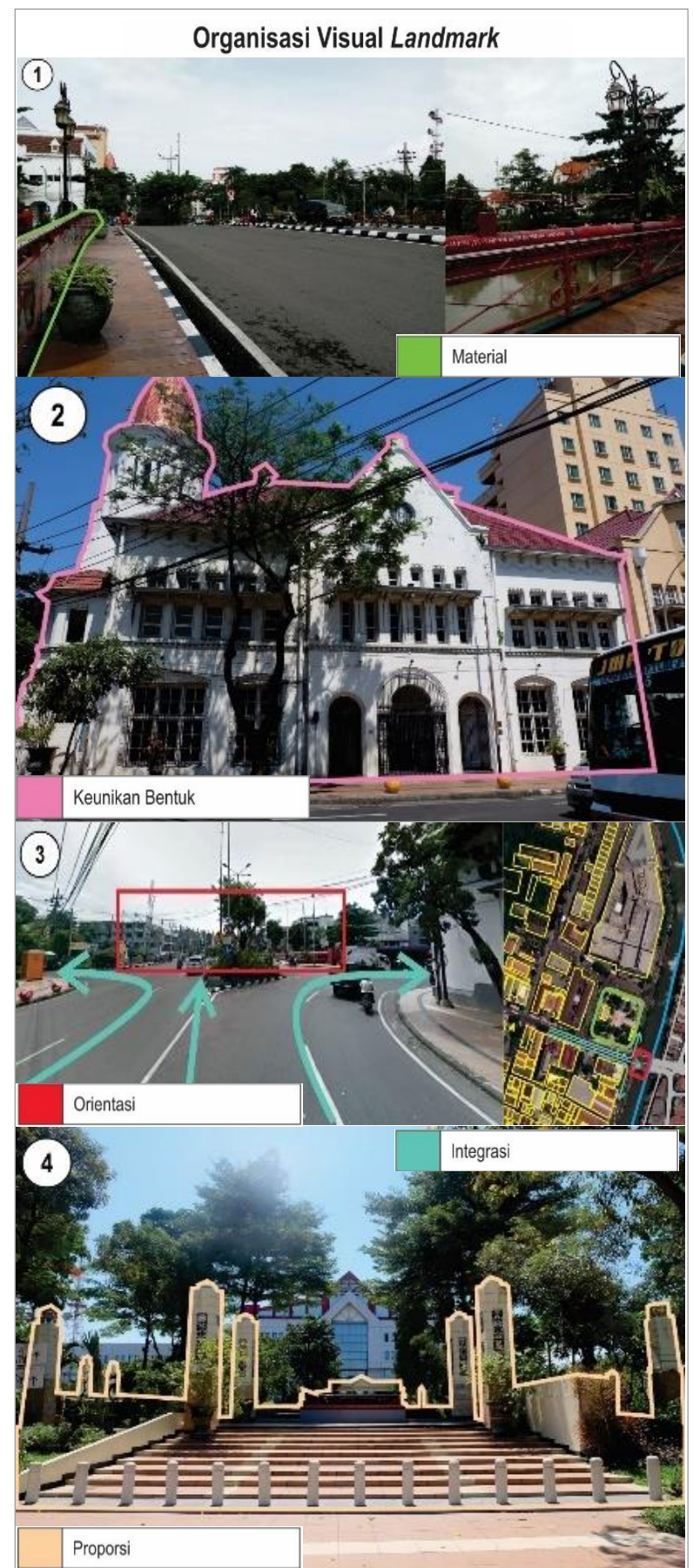

\section{Gambar 11. Organisasi Visual Elemen Landmark}

Perbedaan material objek dengan lingkungan Objek yang memiliki nilai tertinggi untuk kriteria material pada elemen landmark di Kawasan Jalan Rajawali yaitu Jembatan Merah. Perbedaan material objek dengan lingkungan pada Jembatan Merah sangat kuat karena objek tersebut merupakan ruang terbuka dan merupakan penghubung antara Kawasan Jalan Rajawali dengan Kawasan Pecinan, Arab, dan juga pusat pemerintahan baru. Adanya perbedaan material objek dengan lingkungan memperkuat pola disimilarity.

Perbedaan bentuk dengan sekitarnya

Objek yang memiliki nilai tertinggi untuk kriteria keunikan bentuk pada elemen landmark di Kawasan Jalan Rajawali yaitu Gedung Cerutu. Bentuk bangunan gedung cerutu memiliki perbedaan dengan bangunan sekitarnya. Bangunan tersebut memiliki ciri yaitu adanya menara berbentuk cerutu pada sisi kanan bangunan. Hal iniberbeda dengan karakteristik bangunan khas kolonial yang memiliki bentuk yang simetris pada bangunannya. Bentuk tersebut membuat Gedung Cerutu memiliki kesan disimilarity pada kawasan.

Orientasi objek terhadap lingkungan sekitar Objek yang memiliki nilai tertinggi untuk kriteria orientasi pada elemen landmark di Kawasan Jalan Rajawali yaitu Jembatan Merah. Jembatan Merah merupakan salah satu ikon kota lama yang memiliki daya tarik sejarah. Objek tersebut mudah dikenali karena berada di pangkal ruas jalan arteri sekunder dan hanya memiliki arus kendaraan satu arah yang memperkuat orientasi objek terhadap lingkungan sekitar.

\section{Proporsi}

Objek yang memiliki nilai tertinggi untuk kriteria proporsi pada elemen landmark di Kawasan Jalan Rajawali yaitu Taman Jayengrono. Objek tersebut terlihat sangat kontras dengan background sehingga memperkuat kesan figure ground dan disimilarity.

Integrasi dengan objek di sekitarnya

Objek yang memiliki nilai tertinggi untuk kriteria integrasi pada elemen landmark di Kawasan Jalan Rajawali yaitu Jembatan Merah. Objek tersebut memiliki integrasi dengan objek di sekitarnya, antara lain kawasan komersial (pusat perbelanjaan Jembatan Merah Plaza), kawasan cagar budaya sebagai objek pariwisata sejarah dan sebagai penghubung Kawasan Kota Lama dengan kawasan lainnya serta antara Kota Surabaya menuju Madura. 
Hasil pembobotan menunjukkan bahwa Jembatan Merah mendapatkan hasil yang paling tinggi dengan prosentase $14,68 \%$ dan menjadi objek utama elemen landmark di Kawasan Jalan Rajawali.

\section{KESIMPULAN}

Berdasarkan hasil penelitian, maka didapatkan kesimpulan, bahwa objek utama citra kawasan Jalan Rajawali yaitu 1) path adalah Jalan Rajawali, 2) edge adalah Sungai Kalimas, 3) district adalah Kawasan Cagar Budaya, 4) node adalah Taman Sejarah Jayengrono, 5) landmark adalah Jembatan Merah.

\section{UCAPAN TERIMA KASIH}

Penulis menyadari bahwa dalam proses pengerjaan penelitian ini tidak lepas dari dukungan berbagai pihak yang berkenan untuk membantu, memberikan pemikiran, kritik, dan saran. Terima kasih kepada Allah SWT, yang telah memberikan kemudahan dan kelancaran dalam penyusunan penelitian ini. Tak lupa juga untuk keluarga dan sahabat atas motivasi, dukungan serta doa sehingga penelitian ini dapat diselesaikan dengan baik dan lancar. Semoga penelitian ini dapat memberikan kontribusi dan menjadi referensi bagi proses perencanaan dan perancangan citra kawasan, serta dapat berguna sebagai rujukan untuk penelitian sejenis selanjutnya.

\section{DAFTAR PUSTAKA}

Adiwena, D. P. (2015). Revitalisasi Kawasan Rajawali Kota Surabaya. Institut Teknologi Sepuluh Nopember: Surabaya.

Eraydin, Z. (2007). Building A Legible City: How Far Planning is Successful in Ankara. http://etd.lib.metu.edu.tr/upload/12608221.p df

Eren, E. (2013). Inconsistencies (Problem of) Between Two Dimensional Graphic (Urban) Design and It's Three Dimensional (Urban) Forms.http://etd.lib.metu.edu.tr/upload/126 16715.pdf

Essup, H. J. (1985). Dutch architectural visions of the Indonesian tradition. https://doi.org/10.1163/22118993-90000202

Handinoto. (1996). Perkembangan Kota dan Arsitektur Kolonial Belanda di Surabaya, 1870-1940. ANDI Yogyakarta.

Konidari, M. (2006). Multicriteria Analysis - A
manual.http://eprints.lse.ac.uk/12761/1/Mul ti-criteria_Analysis.pdf

Kwanda, T. (2004). Desain Bangunan Baru Pada Kawasan Pelestarian Di Surabaya. DIMENSI (Jurnal Teknik Arsitektur), 32(2), 102-109. http://puslit2.petra.ac.id/ejournal/index.php/ ars/article/view/16181

Lynch, K. (1960). The Image of the City. Massachusetts Institute of Technology and the President and Fellows of Harvard College.

Pettricia, H. A., Wardhani, D. K., \& Antariksa, A. (2014). Elemen Pembentuk Citra Kawasan Bersejarah Di Pusat Kota Malang. Review of Urbanism and Architectural Studies, 12(01), $10-23$.

https://doi.org/10.21776/ub.ruas.2014.012.0 1.2

Purwanto, E. (2001). Pendekatan Pemahaman Citra Lingkungan Perkotaan (melalui kemampuan peta mental pengamat). DIMENSI (Jurnal Teknik Arsitektur), 29(1), 85-92.

http://puslit2.petra.ac.id/ejournal/index.php/ ars/article/view/15748

Subana, S. (2005). Dasar-Dasar Penelitian Ilmiah. Pustaka Setia.

Wati, T. W. I. K. M., \& Sukmajati, D. (2017). Pengaruh Keberadaan PKL terhadap Kualitas Visual Jakarta Universitas Mercu Buana. Jurnal Arsitektur, Bangunan, \& Lingkungan, 6(3), 125-132. 